\title{
Erratum to: 'The educational gradient of obesity increases among Swedish pregnant women: a register-based study'
}

Helena Bjermo ${ }^{1,2^{*}}$, Simon Lind ${ }^{1}$ and Finn Rasmussen ${ }^{1,2}$

Unfortunately, the original version of this article [1] contained an error. The presentation of Fig. 1 was incorrect. The numbers on the Y-axis are incorrect and need modification. The correct version is provided below.

Received: 26 May 2016 Accepted: 26 May 2016

Published online: 15 June 2016

\section{Reference}

1. Bjermo H, Lind S, Rasmussen F. The educational gradient of obesity increases among Swedish pregnant women: a register-based study. BMC Public Health. 2015;15:315.

* Correspondence: helena.bjermo@sll.se

'Unit of Child and Adolescent Health, Centre for Epidemiology and Community Medicine, Stockholm County Council, Box 1497SE-171 29 Solna, Sweden

${ }^{2}$ Child and Adolescent Public Health Epidemiology, Department of Public Health Sciences, Karolinska Institutet, SE-171 77 Stockholm, Sweden

\footnotetext{
Submit your next manuscript to BioMed Central and we will help you at every step:

- We accept pre-submission inquiries

- Our selector tool helps you to find the most relevant journal

- We provide round the clock customer support

- Convenient online submission

- Thorough peer review

- Inclusion in PubMed and all major indexing services

- Maximum visibility for your research
}

Submit your manuscript at

www.biomedcentral.com/submit 


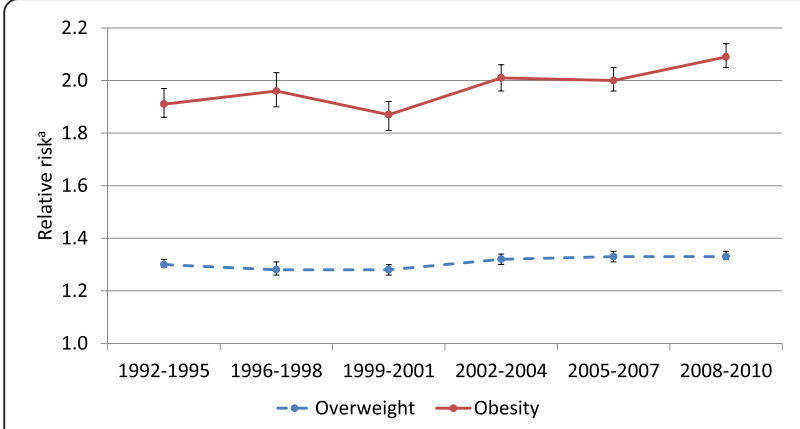

Fig. 1 Time trends in relative risks of overweight and obesity between Swedish nulliparous women with low vs high education. BMI was assessed at the first visit to the antenatal-care clinic. ${ }^{a}$ Relative risk (95\% confidence interval) for overweight/obesity among women with low education compared to higher educated women, adjusted for maternal age 